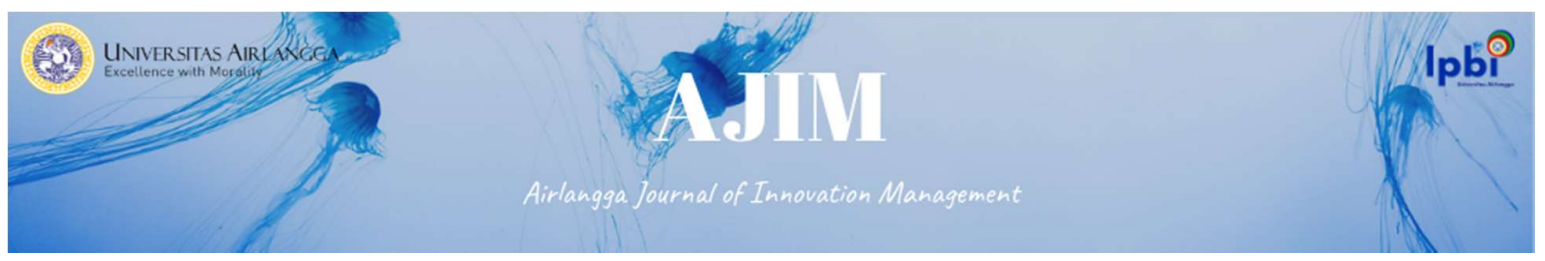

Vol. 1 No.2 Oktober 2020

e-ISSN: 2722-5062

DOI : 10.20473/ajim.v1i1.20392

\title{
MOVIE-INDUCED TOURISM AS A POWERFUL TOURISM BRANDING MEDIA (STUDY CASE ON “LASKAR PELANGI” THE MOVIE)
}

\author{
Mahaning Indrawaty Wijaya ${ }^{1}$, Novi Ahimsa Rosikha ${ }^{2}$ \\ School of Information Systems, Bina Nusantara University ${ }^{1}$ \\ School of Communication and Multimedia, Telkom University ${ }^{2}$ \\ Correspondent e-mail: mahaning.wijaya@binus.ac.id. ${ }^{1}$
}

\begin{abstract}
The scarcity in natural resources encourages many countries to move their focus to manage non-natural resources. The tourism sector is one of the potential non-natural resource in Indonesia that needs to be maximised by appropriate media. The fact that the number of tourists coming to Bangka Belitung increase until about $1.800 \%$ by "Laskar Pelangi" the movie is a good sign that movie can be a tourism branding media to increase the desire of audiences to visit the place which is shown. This research examines how "Laskar Pelangi" as movie-induced tourism can influence audience decision to visit Belitung Island using a combination of quantitative and qualitative research. The result shows that Laskar Pelangi is effective in movie-induced tourism since it has both pull and push factors. Understanding this tourism strategy will allow the nation to excel economy recovery in the future.
\end{abstract}

Keywords: Movie, Tourism, Economics.

ABSTRAK

Kelangkaan sumber daya alam mendorong banyak negara mengalihkan fokusnya untuk mengelola sumber daya non-alam. Sektor pariwisata merupakan salah satu potensi sumberdaya non alam di Indonesia yang perlu dimaksimalkan. Fakta bahwa jumlah wisatawan yang datang ke Bangka Belitung meningkat hingga sekitar $1.800 \%$ dengan adanya film "Laskar Pelangi" merupakan pertanda baik bahwa film dapat menjadi media branding pariwisata untuk meningkatkan keinginan penonton mengunjungi tempat yang ditayangkan. Penelitian ini mengkaji bagaimana "Laskar Pelangi" sebagai film yang memicu pariwisata dapat mempengaruhi keputusan penonton untuk mengunjungi Pulau Belitung dengan kombinasi penelitian kuantitatif dan kualitatif. Hasil penelitian menunjukkan bahwa Laskar Pelangi merupakan pariwisata induksi film yang efektif karena memiliki faktor penarik dan pendorong. Memahami strategi pariwisata ini memungkinkan bangsa untuk unggul dalam pemulihan ekonomi di masa depan.

Kata Kunci: Film, Pariwisata, Ekonomi.

\section{INTRODUCTION}

Movie-induced tourism is a film which convinced to encourage the tourist's desire to visit the place shown in film. This is an interesting phenomenon to be researched considering the high prospect of tourism sector to substitute the income from natural resources. Nowadays, the scarcity in natural resources encourage many countries move their focus to manage non-natural resources. As discussed by Shammas, Zalfa, et al. (2006), the most rapid economic growth occurred in Arab Emirates, especially Dubai City that increased $10 \%$ per year after moving their focused income from gas and oil to tourism sector. This fact reminds us that Indonesia also has great potential in tourism sector. The World Economic Forum 2019 reported that effectiveness levels of marketing and branding of Indonesian tourism sector is in position 40, left behind from Malaysia (29) and Thailand (31). However, this rank is improved compared to a decade ago when Indonesia's rank was $56^{\text {th }}$. This means Government start to focus to improve Indonesia tourism. Beside improving the tourism facility, another strategy to improve tourism is by influencing people perspective through decent branding. This branding strategy could be maximized by utilizing appropriate 
media. The fact that number of tourist coming to Bangka Belitung increase until about $1.800 \%$ after the release of Laskar Pelangi The Movie (Darwance, 2017) is a sign that movie can be tourism branding media to increase desire of audiences to visit the place which is shown.

Since the release of Laskar Pelangi The Movie, the condition of economical society in Belitung Island is improved. The societies that usually depending their life on natural resources like mining and farming, nowadays also get income from the growth of tourism sector. This encourages many new micro industries, such as gift handicraft, also grow. This condition said by Syarief Hasan (Indonesian Minister of Cooperatives and Small-and Medium Scale Enterprises) at the opening of Belitong Beach Festival and Expo 2013. He said that Bangka Belitung has been grown as a province with high level economy and low level of poverty signed by the growth of small scale enterprises which absorb many labors (Pratiwi and Evani, 2013).

In macro condition, as reported in "Kajian Ekonomi Regional Provinsi Kepulauan Bangka Belitung Triwulan III 2011" that published by Bank Indonesia, tourism sector has a big role and become a promising sector. The paper also reports that from 2008, there is a significant declining in mining Industry, but this condition is well substituted by the growth of farming and tourism sector. Here is the growth of tourist coming to Belitung Island.

Figure 2 The growth od Tourist Coming to Belitung Island

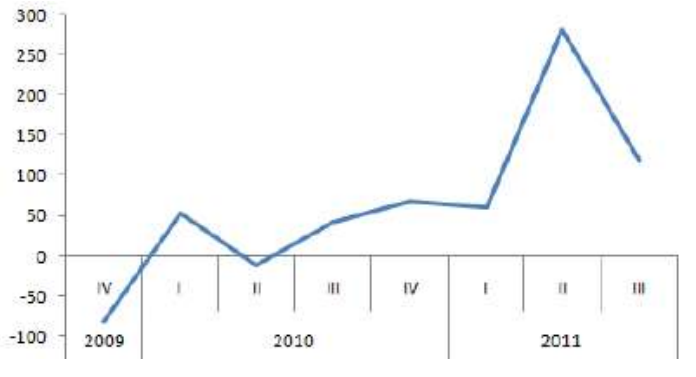

Source: BPS Bangka Belitung as shown in "Kajian Ekonomi Regional Provinsi Kepulauan Bangka Belitung Triwulan III 2011”, p.12

The number of tourists grows well every year. The growth of tourism sector also influences the growth of transportation sector, communication, and restaurant in Belitung. Tourism sector encourages other sectors to grow more. Although Tourism sector currently faces challenges due to COVID-19, this sector will contribute to the economy recovery in the future.

\section{LITERATURE REVIEW}

\section{1) Laskar Pelangi The Movie and Belitung Island}

Laskar Pelangi (En: The Rainbow Troops) is an Indonesian box office movie directed by Riri Reza (Imanjaya and Kusumawardhana, 2018). This movie is adapted from a same titled novel by Andrea Hirata that tells about a group of schoolchildren and teachers live in Belitung whostruggle with poverty and develop hopes for the future in Gantong Village on the farming and tin mining island of Belitung. This movie is very motivational. It shows despite of the lack access of education and poor facility to support education process in Belitung Island, the teachers have high ambition to improve student's motivation to study, and the students who have difficult condition did not give up to go to school (Hirata, 2005). Beside the inspirational story, beautiful place also one of the attractiveness of The Movie. Belitung Island is shown as a charming island decorated by beautiful beaches and stunning scenery.

Belitung is an island on the east coast of Sumatra which is known for its tin mining. Despite the rich natural resources, Belitung Island have high rate poverty. In 2010, Belitung was $8^{\text {th }}$ province with the highest poverty rate (Andriansyah, et al., 2012). Before the release of Laskar Pelangi The Movie, only few tourists come to Belitung, however it surges significantly after the release (Imanjaya and Kusumawardhana, 2018). Several places shown in The Movie now become highly popular spot to visit, such as Pantai Tanjung Tinggi, Laskar Pelangi school (SD Muhammadiah Gantong) and Andrea Hirata Museum (Ibrahim et al., 
2019). Because of this, currently Belitung Island is also known as "Negeri Laskar Pelangi" (Humas Kab. Belitung, 2013).

\section{2) Movie-Induced Tourism}

There have been several research examining the relationship between film/ movie and tourism. However, the initial framework which focusing on audience perspective and specifically examine the impacts of film on audience was first proposed by Macionis (2004). The concept called 'Film-induced tourism'. The concept made to express the visits made to corresponding site which is influenced from audiovisual shown in The Movie (Cardoso et al., 2017). To classify type of tourist that visit a tourism site. Macionis (2004) classified 3 continuums of movie-induced tourist, namely; Serendipitous Film Tourist, General Film Tourist, and Specific Film Tourist which are shown in the Figure 1.

Figure 1. Continuum of Movie-Induced Tourist

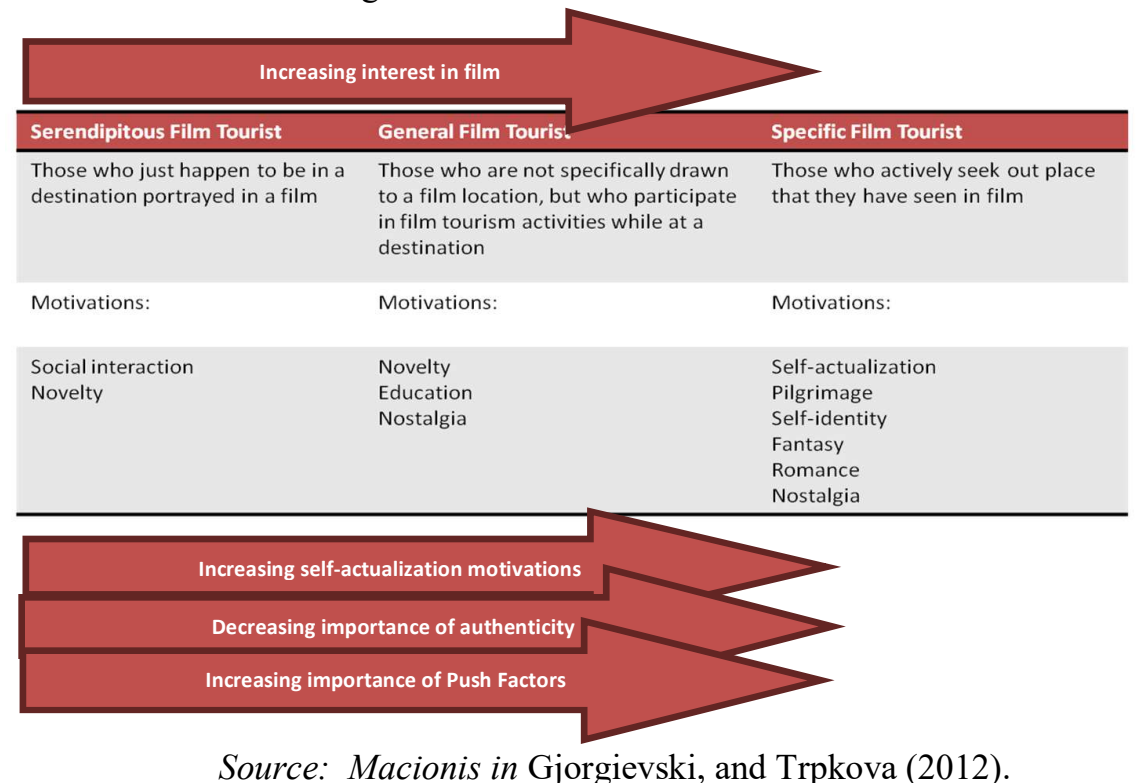

Serendipitous film tourist visits a tourism site drive by authenticity of the place. For example, tourist visit Haghia Sophia Museum is motivated by the beautiful structure and it's long history of religion heritage. Meanwhile, specific film tourist visits a place because their fantasy which comes from the place, storyline, and character they see in the film such as tourist visits to Hobitton movie set in New Zealand after watching Lord of The Ring (Kraaijenzank, 2009). Movie-induced tourism purpose is to shift people from Serendipitous film tourist to Specific Film Tourist, and therefore it is often utilized as a means of marketing strategy to promote tourism destination (Millán et al., 2016). Initially, Macionis stated that toward the continuum from Serendipitous film tourist to Specific Film there is increase of interest in film and selfactualization. Later Gjorgievski and Trpkova (2012) adding the decrease importance of authenticity and increasing important of push factors in the continuum of change from Serendipitous film tourist to Specific Film Tourist.

Gjorgievski and Trpkova (2012) cited Macionis (2004) explained The Movie-induced phenomenon based on "pull and push" factor. Push factor comes from audience itself, which is related to something that encourage them to visit a place from watching the movie. It is represented by some aspect such as exploration and evaluation of self, relaxation, escape, social interaction, and education. Mascionis (2004) gave example of push factors;

1) to satisfy needs of socialisation with family and friends;

2) to satisfy needs of escape with rest and recreation; or

3) to satisfy sun lust desires to get sun-tanned

Whereas pull theory is related to something that attracts the audience to visit the place which is represented by 3P: Place, Personality, and Performance. Place is the location where The Movie (or particular scene) is shot, whether it real (e.g. Laskar Pelangi) or fictional (e.g. Lord of The Ring). It involves film location attributes, such as unique scenery or landscapes which are quickly identifiable and attractive 
to an audience (Mascionis, 2004). Research conducted by Chan (2007) in examining influence of Korean TV Drama and the intention to visit the shown place showed that audience primarily visit a tourism destination because they wanted to validate architecture and landscape (push factor) which appear as a place or background location in the film (pull factor). Performance provokes audience curiosity from the screenplay, storyline, customs, and tradition. This also includes particular stories and genres, that is the plot's drama, the elements of the theme and people experience's in the film (Mascionis, 2004). Lastly, personality is factor which involves characters and actors who played the character in The Movie (Gjorgievski and Trpkova, 2012). Beside the inspirational character that movie has, famous stars are powerful ingredient of mass media, especially film/ movie. Pearce, Morrison and Moscardo (2003) stated that without the right marketing strategy, people who interest to come to museum, shrines and sites only they who have specific interest on literature, music or artistical things which the number may be very limited.

\section{METHODS}

This research used combination of quantitative and qualitative method. Kasiram (2008) stated that quantitative method is a method that used number as a means to analyze information. This research used quantitative method to know if pull and push factor of Laskar Pelangi The Movie have influence on the decision of audience to visit place shown in The Movie (Belitung Island). To answer that, two hypotheses were tested.

$\mathrm{H}_{1}=$ There is impact of pull and push factor of Laskar Pelangi The Movie toward the desire of audience to visit Belitung Island simultaneously

$\mathrm{H}_{2}=$ There is impact of pull factor of Laskar Pelangi the movie toward the desire of audience to visit Belitung Island partially

$\mathrm{H}_{3}=$ There is impact of push factor of Laskar Pelangi the movie toward the desire of audience to visit Belitung Island partially

Online questionnaire was developed and distributed to audience who have watched Laskar Pelangi The Movie. In total, from 4.606.785 population of people watched Laskar Pelangi The Movie (Mulyadi and Sunarti, 2019), 100 sample are collected based on Slovin method. Formula 1.1 aims to calculate the sampling size (Notoatmodjo, 2012).

$$
\begin{aligned}
& \mathrm{n}=\quad \frac{\mathrm{N}}{1+\mathrm{Ne}^{2}} \\
& \mathrm{n}=\frac{4.606 .785}{1+4.606 .785(0,1)^{2}} \\
& \mathrm{n}=99,99 \text { or } 100
\end{aligned}
$$

After online questionnaires were distributed, demographic of respondents which answering questionnaire was obtained. Figure 2 shows the composition of age group of the respondent.

Figure 2. Composition of age group of the respondent

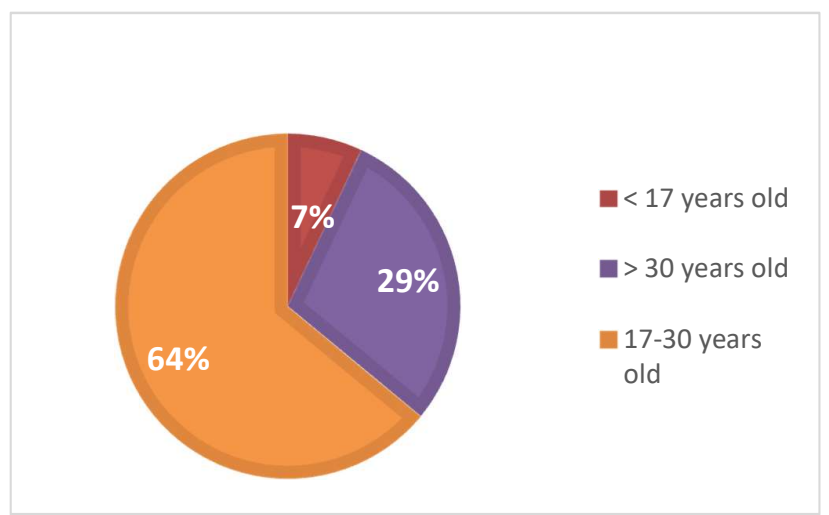

Source: Data collected by authors (2020) 
It can be seen from the figure that the majority of respondent was in the age group of 17-30 years old, followed by aged group of $>30$ years old, and only a few respondents come from aged group of $<17$ years old. This could be expected since Laskar Pelangi The Movie itself was released on 2008 (12 years ago), thus the percentage of people who watch Laskar Pelangi The Movie who is currently under 17 years old is not many. The hype period of this movie resulted more respondent come from age group 17-30 years old and $>30$ years old. From the gender perspective, Figure 3 shows that most of the respondent of the survey was woman. From the sample size, woman representation was $62 \%$ while man representation was $38 \%$.

Figure 3. Composition Of Gender Of The Respondent

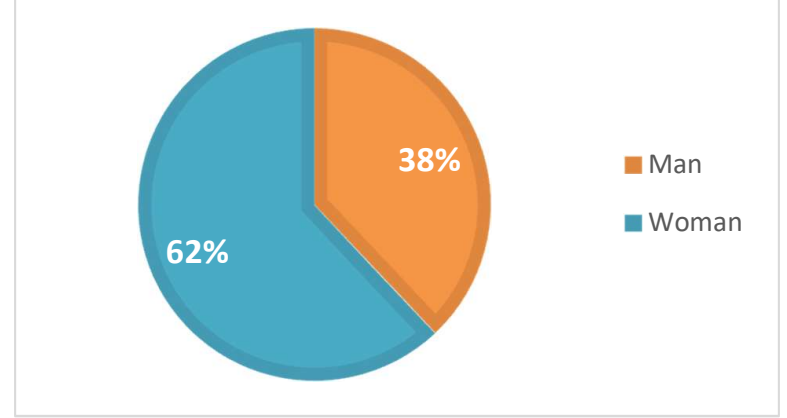

Source: Data collected by authors (2020)

The quantitative data obtained from the questionnaire then is processed and analyzed with multiple linear regression using SPSS software. The formulation of this research can be seen in figure 4 .

$$
\mathrm{Y}=\alpha+\beta 1 \mathrm{X} 2+\beta 2 \mathrm{X} 2
$$

$\mathrm{Y}=$ Dependent variable (Audience desire to visit the place)

$\mathrm{X} 1=$ Independent variable (Push factors)

$\mathrm{X} 2=$ Dependent variable (Pull factors)

$\alpha=$ Constant

$\beta 1=$ Coefficient estimate of Push factors

$\beta 2=$ Coefficient estimate of Pull factors

Besides that, qualitative method is used to understand the phenomenon experienced by the research subject such as perception, motivation, action, in a holistic way by describing in a words and languages in a specific context using various natural methods (Moleong, 2007). Qualitative was obtained through literature review to have deeper explanation the influence of Laskar Pelangi The Movie to the increase of tourism activity in Belitung Island.

\section{RESULTS AND DISCUSSION}

\section{1) Impact of pull and push factor of Laskar Pelangi The Movie toward the desire of audience to visit Belitung Island simultaneously}

This research used $95 \%$ confidence level in analysing the simultaneous impact of pull and push factor of Laskar Pelangi The Movie toward the desire of audience to visit Belitung Island. The method used is to look at the level of significance $(=0.05)$. If the significance value is less than 0.05 , then $\mathrm{H} 0$ is rejected and $\mathrm{H} 1$ is accepted. The result of the calculation is shown in Table 1. 
Table 1.

Influence of Push And Pull Factors Simultaneously to the Desire of Audience to Come to Belitung Island

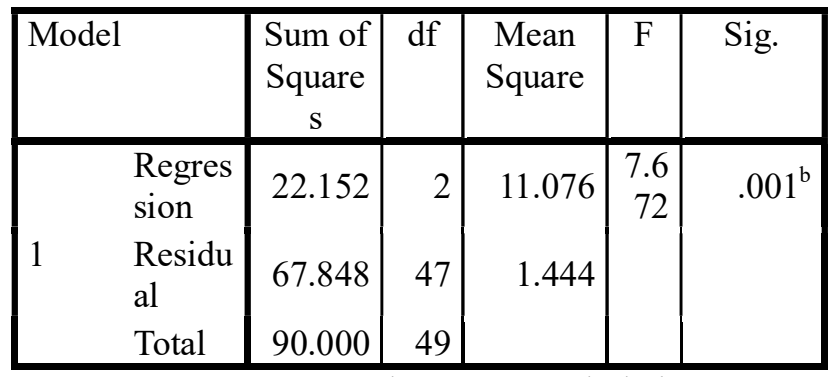

Source: Author's Data Tabulation

It found that $\mathrm{Sig}=0.001$ and it is less than 0.05 , which indicates that $\mathrm{H}_{1}$ is accepted. It means push and pull factors simultaneously influence the desire of audience to come to Belitung Island. So, in influencing the desire of audience to come to Belitung Island, Laskar Pelangi has both pull and push factors as a movieinduced tourism.

\section{2) Impact of pull and push factor of Laskar Pelangi The Movie toward the desire of audience to visit Belitung Island partially}

Partial test ( $\mathrm{t}$ ) is used to understand how far the independent variables individually have impact on dependent variable. This test carried out using $95 \%$ confidence level or in the other words $5 \%$ significance level. If the significance value is less than 0.05 , then $\mathrm{H}_{0}$ is rejected and $\mathrm{H}_{2}$ and $\mathrm{H}_{3}$ is accepted respectively. The result of the calculation is shown in Table 2.

Table 2.

Influence of Push And Pull Factors Partially to the Desire Of Audience to Come to Belitung Island

\begin{tabular}{|c|c|c|c|c|c|c|c|c|c|c|}
\hline \multirow[t]{2}{*}{ Model } & \multicolumn{2}{|c|}{$\begin{array}{c}\text { Unstandardized } \\
\text { Coefficients } \\
\end{array}$} & \multirow{2}{*}{$\frac{\begin{array}{c}\text { Standardized } \\
\text { Coefficients }\end{array}}{\text { Beta }}$} & \multirow[t]{2}{*}{$\mathrm{t}$} & \multirow[t]{2}{*}{ Sig. } & \multicolumn{3}{|c|}{ Correlations } & \multicolumn{2}{|c|}{$\begin{array}{c}\text { Collinearity } \\
\text { Statistics } \\
\end{array}$} \\
\hline & B & $\begin{array}{l}\text { Std. } \\
\text { Error }\end{array}$ & & & & $\begin{array}{l}\text { Zero- } \\
\text { order }\end{array}$ & Partial & Part & Tolerance & VIF \\
\hline (Constant) & 3.129 & 1.358 & & 2.305 & .026 & & & & & \\
\hline $1 \mathrm{PUSH}$ & .105 & .066 & .271 & 1.589 & .119 & .453 & .226 & .201 & .550 & 1.817 \\
\hline PULL & .068 & .043 & .272 & 1.592 & .118 & .453 & .226 & .202 & .550 & 1.817 \\
\hline
\end{tabular}

Source: Author's Data Tabulation (2020)

From above table of partial analysis, the result shows that Sig Push $=0.119$, which is not less than 0.05 , which indicates that $\mathrm{H}_{2}$ is rejected. This means push factors only does not influence the desire of audience to come to Belitung Island. The table also shows that. Sig Pull $=0.118$ which is not less than 0.05 , and indicates that $\mathrm{H}_{3}$ is rejected. It means pull factors partially doesn't influence the desire of audience to come to Belitung Island. So, if Laskar Pelangi has push factor only or pull factor only, it cannot influence the desire of audiences to come to Belitung Island. In the other words, this study reveals that movie-induced tourism will be effective if push factors and pull factors exist.

Descriptive statistics result in Table 3 shows level importance of each factors in push factors category in influencing audience. Factor which has higher Mean imply high level importance compare to the lower mean. From Table 3, motivation and escape are two push factors that have big impact to the audiences of Laskar Pelangi. This means, what drives audiences to the decision to visit tourism destination is an internal motivation to travel and seek to visit a place to escape from a routine. Beach is one of the destinations that attracts many people in holiday or leisure time. Thus, beach scenery shown in the Laskar Pelangi The Movie trigger motivation and escape factors which audience has. 
Table 3.

Descriptive Statistics of Push factors

\begin{tabular}{|l|r|r|}
\hline & Mean & $\begin{array}{c}\text { Std. } \\
\text { Deviation }\end{array}$ \\
\hline X11 Motivation & 3.98 & .714 \\
\hline X12 Fantasy Perceived & 3.68 & .913 \\
\hline $\begin{array}{l}\text { X13 } \\
\text { experience }\end{array}$ & 3.64 & .749 \\
\hline X14 Escape & 3.88 & .746 \\
\hline X15 Self Esteem & 2.68 & .913 \\
\hline X16 Self Identity & 3.04 & .947 \\
\hline X17 Personal urge & 3.76 & .916 \\
\hline
\end{tabular}

Source: Author's Data Tabulation (2020)

Whereas in pull factors, which can be seen in Table 4, the interesting scenery and story is the factor that highest importance level in attracting audiences. Beautiful scenery of Belitung Island shown in The Movie such as clear sea, a view of the fantastic formation of rocks scattered along the offshore leads audience desire to visit the place. The great screenplay of Laskar Pelangi which tells about inspirational story about the characters who struggle to study in a restrictiveness condition is a also have strong impact which drive the desire of audience to come to Belitung Island.

Table 4.

Descriptive Statistics of Pull factors

\begin{tabular}{|l|r|r|}
\hline & Mean & \multicolumn{1}{|c|}{$\begin{array}{c}\text { Std. } \\
\text { Deviation }\end{array}$} \\
\hline $\begin{array}{c}\text { X21 Infrastructure and } \\
\text { facility }\end{array}$ & 3.22 & .790 \\
\hline X22 Scenery & 4.38 & .635 \\
\hline X23 Climate & 3.42 & .971 \\
\hline X24 Indigenous Culture & 3.84 & .766 \\
\hline X25 Social life & 3.74 & .803 \\
\hline X26 Activity & 3.72 & .757 \\
\hline X27 Film quality & 3.66 & .745 \\
\hline X28 Story & 4.00 & .728 \\
\hline X29 Customs Scene & 3.74 & .694 \\
\hline X210 Character & 3.24 & 1.001 \\
\hline X211 Actors/ Actrees & 2.76 & 1.061 \\
\hline Source: Author's Data Tabulation $(2020)$ \\
\hline
\end{tabular}

Besides that, based on qualitative analysis it can be said that tourists come to Belitung Island are shift from Serendipitous Film Tourist to Specific Film Tourist. That means tourist who visit Belitung Island is not merely driven by the authenticity or beautiful nature it has, but rather because influenced by Movieinduced tourism, in this case, Laskar Pelangi The Movie. It is also supported by research done by Nofiyaniet al. (2019) that showed the main reason tourists come to Belitung is to visit Negeri Laskar Pelangi, see Muhammadiyah Gantong school, and Batu Berlayar beach. Those sites were largely shown in Laskar Pelangi The Movie. It also showed that most people come to Belitung initially did not know about the island before watching Laskar Pelangi.

To answer this opportunity, government also called Belitung Island as "Negeri Laskar Pelangi as a branding strategy to attract the people to come to Belitung. It also seems from the government effort who continuously manage and improve the Belitung Island facilities to make the visitor feel the atmosphere of Laskar Pelangi The Movie. Government seriously manage Pantai Tanjung Tinggi, one of the most beautiful 
beaches in the country which is portrayed in The Movie currently is managed by government. Government also revitalized Tanjung pandan port and rename it to Laskar Pelangi port (Humas Kab. Belitung, 2013). Additionally, Laskar Pelangi school (SD Muhammadiah Gantong) is preserved and Andrea Hirata museum is built to increase 'Laskar Pelangi The Movie' atmosphere to audience.

\section{CONCLUSION}

The study case of Laskar Pelangi The Movie shows that push and pull factors simultaneously affects the desired of the audience to visit places shown in the movie. People come to Belitung Island because they are pushed by their internal drives such as motivation and escape, and simultaneously pulled by the attractive Laskar Pelangi The Movie such as Scenery and Story. Therefore, tourists come to Belitung Island mostly are Specific Film Tourist, which visit the Island not because of the authenticity but seek to feel the experience of Laskar Pelangi The Movie. This can be an evidence that an effective movie-induced tourism should simultaneously have both pull and push factors. Government could use this movie-induced tourism strategy in the future to promote Indonesia tourism. This can be done by utilizing a tourist destination as a background location in The Movie and targeting audience who has motivation and escape factor to tourism activity. Thus, tourism in Indonesia can be optimized and contribute to the economy development, also becomes a good solution to substitute the natural resource industry which has the problem of scarcity.

\section{REFERENCES}

Andriansyah, et al. (2012), Novel dan Film Media Pemicu Pengembangan Pariwisata dalam Menanggulangi Kemiskinan. In: Seminar Nasional FISIP-UT 2012

Bagian Humas Pemerintah Kabupaten Belitung (2013), Potret Belitung: Negeri Laskar Pelangi. Retrieved from; https://portal.belitungkab.go.id/asset/files/pdf/potret belitung.pdf

Blanke, Jennifer and Thea Chiesa (2011), The Travel and Tourism Competitiveness Report 2011. World Economic Forum, 2011

Calderwood, Lauren Uppink and Maksim Soshkin (2019). The Travel \& TourismCompetitivenessReport 2019. World Economic Forum.

Chan, B. (2007). Film-Induced Tourism in Asia: A Case Study of Korean Television Drama and Female Viewers' Motivation to Visit Korea. Tourism Culture \& Communication, 7(3), 207-224. doi: $10.3727 / 109830407782212510$

Darwance(2017). Pelestarian Kearifan Lokal Sebagai Potensi Daya Tarik Wisata Melalui Kebijakan Bidang Legislasi 1. ProsidingKoferensiKearifanLokal: Nilai, Praktik, dan TantanganPerubahan

Fifi Nofiyantiet al. (2019), Ekranisasi Karya Sastra Traveling Sebagai Media PromosiWisata Indonesia. Jurnal IKRA-ITH Humaniora Vol 3 No 3 Bulan November 2019.

Gjorgievski ,Mijalce and SinolickaMellesTrpkova. Movie Induced Tourism : A new Tourism Phenomenon, UTMS Journal of Economics, 2012, pp.99-101

Hirata, Andrea (2005), Laskar Pelangi. Penerbit Bentang Pustaka. Yogyakarta

I Ibrahim et al.(2019),Between Natural Tourism, the Booming of Laskar Pelangi Film, and theImage of Environmental Damage: Measuring the Perception of RegionalTourist on Bangka Belitung Tourism. Journal of Physics.: Conference Series 1351012107.

Kantor Bank Indonesia Palembang (2011), Kajian Ekonomi Regional Provinsi Kepulauan Bangka Belitung Triwulan III - 2011, 2011, p.12

Kraaijenzank, M. (2009). Movie-Induced Tourism An analytical report on how the Lord of the Rings trilogy has affected tourism in New Zealand. Master Thesis. Aalborg University

Kusumawardhana, Indra and Ekky Imanjaya (2018) Film Tourism Indonesian Style: The Cases of Laskar Pelangi and Eat Pray Love, Communicare Vol 3 No 2.

Kasiram, Mohammad (2008),Metode Penelitian Kuantitatif-Kualitatif. Malang: UINMalang Press.

Lucília Cardosoet al. (2017), Understanding the Film-Induced Tourist. Film-induced tourism: a systematic literature review. Tourism \& Management Studies, 13(3), 2017, pp 23-30.

Macionis, Niki (2004), Understanding the Film-Induced Tourist. In Proceedings of the International Tourism and Media Conference, Tourism Research Unit, Monash University, Melbourne, Australia, 24-26 November 2004, ed. W. Frost, W. C. Croy and S. Beeton, 86-97. Melbourne: Tourism Research Unit, Monash University

Metahumaniora, 9(3), 340. https://doi.org/10.24198/mh.v9i3.25810 
Millán, Á., García, J. A., \& Díaz, E. (2016). Film-induced tourism: A latent class segmentation based on satisfaction and future intentions. PASOS Revista de Turismo y Patrimonio Cultural, 14(4), 875888. https://doi.org/10.25145/j.pasos.2016.14.057

Moleong, Lexy J. (2007), MetodologiPenelitianKualitatif. PT RemajaRosdakaryaOffset Publisher, Bandung

Mulyadi, R. M., \& Sunarti, L. (2020). Film Induced Tourism Dan Destinasi Wisata Di Indonesia.

Notoatmojo, S. (2012). Metodologi Penelitian Kesehatan. Jakarta, Rineka Cipta.

Pearce, P., A. Morrison,. and G. Moscardo (2003), Individuals as Tourist Icons: A Developmental and Marketing Analysis. Journal of Hospitality and Leisure Marketing 10(1/2): 63-85

Pratiwi, Nona Dian and Evani. (2013), Menteri Koperasi \& UKM RI : Perekonomian yang tinggi melalui Potensi UKM dan Pariwisata Babel. Babel Prov Website, Retrieved from: http://www.babelprov.go.id/?q=content/menteri-koperasi-ukm-ri-perekonomian-yang-tinggimelalui-potensi-ukm-dan-pariwisata-babel

Pearce, P., A. Morrison,. and G. Moscardo (2003), Individuals as Tourist Icons: A Developmental and Marketing Analysis. Journal of Hospitality and Leisure Marketing 10(1/2): 63-85

Shammas, Zalfa, et al.(2006), The Natural Resource Curse. The Way Out, EMDC Project Paper, 2006, p.3. 